\title{
DOGS' AGGRESSIVE BEHAVIORS \\ PART II. BODY POSTURES, SEQUENCE OF ACTIONS
}

\section{AGRESYWNE ZACHOWANIA PSÓW CZEŞĆC II. POZY, SEKWENCJA ZACHOWAŃ} Department of Cattle, Sheep and Milk Evaluation, Siedlce University of Natural Sciences
and Humanities, Poland

\begin{abstract}
Streszczenie. Rozpoznanie zachowania agresywnego psa związane jest bezpośrednio z umiejętnością rozróżniania sygnałów, które zwierzę wysyła do drugiego osobnika. W drugiej części pracy starano się przybliżyć charakterystykę poszczególnych sygnałów oraz zachowań, jakie mogą one wywołać. Zwrócono również uwagę na ocenę i prognozowanie zachowania agresywnego czworonogów, dzięki któremu człowiek jest w stanie lepiej przygotować się na kontakt ze swoim pupilem i w prawidłowy sposób odczytywać jego intencje.
\end{abstract}

Key words: aggression, kind of aggressions, aggressive behavior.

Słowa kluczowe: agresja, rodzaje agresji, zachowania agresywne.

\section{INTORDUCTION}

Aggressive actions in dogs start with taking a characteristic body posture. Intensification of the stimulus causes a response that is in accordance with the dog's experience, physiology, and motivation. Aggressive actions may be reactive or instrumental. The former aggression type occurs when the animal has been provoked to attacking or experienced an aversive stimulus, most often caused by pain. Intensifying the negative stimulation leads to a higher number of attacks which may also be more intense. This is instinctive aggression, which means it has not been acquired and is different for every species. Instrumental aggression is aimed at a positive result for the animal (escape, avoidance, gaining something desired). The dog inspects the surrounding and, if notices anything apparently linked to a negative experience, makes all efforts to stop it. The more positive reinforcement experienced, the stronger and more frequent are responses to aversive stimuli (Kokocińska and Kaleta 2015).

Corresponding author - Adres do korespondencji: Elżbieta Horoszewicz, Department of Cattle, Sheep and Milk Evaluation, Siedlce University of Natural Sciences and Humanities, Bolesława Prusa 14, 08-110 Siedlce, Poland, e-mail: ehoroszewicz@wp.pl 


\section{AGGRESSIVE BEHAVIOR: DISPLAYING POSTURES, SEQUENCE AND RECURRENCE OF RESPONSES}

Capability of perceiving communication signals is important in diagnosing aggressive behavior. This allows us to predict subsequent reactions, find factors preceding the attack, and see the effect that the animal wanted to achieve. Dogs use body language, vocalizations and scent to communicate information. Disturbance preventing the proper understanding of the information sent by the dog may result in misunderstanding of intentions and, possibly, in conflict. Through observation, we can catch how the state of animal's mind affects its body posture. These include the position and movements of the animal's back, head, tail, ears, facial expressions and eye orientation. The stance of the dog is named after the position of its back. A tall posture may communicate domination or self-confidence. A low stance, on the other hand, means a low level of self-confidence and fear. This posture is assumed in attempt to calm the other dog down; the body is as if contracted, neck and head withdrawn, legs slightly crouched, tail low or tucked. An ambivalent posture expresses self-confidence mixed with signs of uncertainty. The dog displays this posture if uncertain what it wants or if surrounded by other dogs, to which it has contradicting attitudes (Fleischer 2003; Fiszdon and Boruta 2012). Body postures are accompanied by affiliative behavior aimed to show friendliness, interest and to build trust. One such way is an invitation to play, showing gleam in the eyes, panting, clumsy slow gait (like puppies usually do), and the inviting bow with front legs lying on the ground (Fleischer 2003; Hsu 2010). Agonistic behavior is intended to bring reassurance. Signals include yawning, nose licking, freezing posture, turning head away, quick or slow tail wagging, lying down with belly up, walking along a curve, sniffing the ground, blinking eyes.

We can also distinguish ambiguous, appeasing and aggressive signals, whose message is the will to increase the distance. This is a posture of a frightened dog, sending alternating calming or warning signs, depending on the reaction of the opponent. The aggressive signs, which include stiffened and leaning forward body with widely spaced paws and intense eye contact, are most often shown before a violent attack. During a friendly fight, however, the animals play the roles of hunter and prey and we can see aggressive and affiliative messages. It looks as if one of the participants blocks the movements of the companion, puts a paw or snout on the other dog's neck.

The reaction of the prey-acting partner is what determines the development of the encounter. It also happens that the desire to avoid a stimulus pushes the individual into another negative stimulus, or the dog wants to be in two different places at the same time. The dog showing confusing signals does not know what it wants to achieve. This is what is called conflicting motives. A man-fearing dog, which still is seeking contact with people, is a good example of this situation. One solution to conflict is to use shut-off signals in order to break contact with the opponent. These signals give the dog a way out and prevent a possible chase. Turning head away, nervous licking and avoiding eye contact are examples of shut-off signals (McFarland 1999; Haverbeke et al. 2009).

Emotions evoked by strong stimuli, called emotional triggers, are aggression-releasing factors. Each excitation activates motor centers in the brain, which tend to stabilize and tranquilize the system. A range of specific motor actions are aimed to bring the behavior back to equilibrium. In the case of aggression, four phases are observed: 
1. Disturbance in the system equilibrium, which creates an immediate need to restore it. Here come initial actions, such as threats or trying to intimidate the opponent.

2. Development of the action, i.e. the impact on the neighborhood. The animal fulfills its intentions through an attack.

3. Feeling of release, return of the body to equilibrium, loss of negative emotions and hostility.

4. Relaxation - the dog has received the prize and is unresponsive to irritating impulses.

Through intensification of aversive impulses, these phases escalate provocative events and eventually lead to attack or any other aggressive behavior. Each individual has a threshold resistance to unpleasant factors, sometimes a slight provocation causes an outbreak of aggressive behavior, which ends up with an intense reaction of the body. This is called a catalyst model of aggression. It is important to follow the sequence of stages that form a fixed integrity. This allows the observer to predict the subsequent behavior and to skillfully adapt to it. Any disturbance that causes a change in this sequence should be treated as a pathological case (Horn 2013; Kuhne 2016).

\section{KINDS OF AGGRESSION}

Canine aggressive behavior is a normal phenomenon, which gives advantages to both the pack and the individuals. Aggression acts are often essential in territorial protection, foraging, or hierarchic struggling. They are also classified depending on the target: humans, animals or moving objects (Duffy 2008).

Modern science provides aggression classifications in relation to its function, type of behavior, and body posture. The most common types of aggression:

Dominance aggression - in nature, this type of aggression is harmless or even desirable. A pack of dogs, in order to successfully hunt and survive, needs to establish and maintain internal hierarchy. The problem begins when an act of domination happens in the human environment. We are able to distinguish between defensive and offensive domination. Defensive domination is when the dog defends itself, a human or territory. It emerges also when the individual's distance, or the zone of safety and comfort, has been compromised. Offensive domination means that the dog approaches a person or animal explicitly in order to launch an attack. Ritualized gesture system allows gaining domination over the opponent and preventing a fight. The set of gestures, such as raised tail, chest pushed forward and head held high, are signs of a dominant dog. The attack is launched if the dominant dog receives no signs of submission from the opponent or if the latter fails to flee (Drews 1993).

Intraspecific aggression - it most often results from the hierarchic instinct. Males are generally problematic for other males, but not for the opposite sex. On the other hand, females may show aggression against other females if more than one live in the same household. Improper intervention can exacerbate the conflict. This may happen if we favor the weaker individual or treat it on a par with the stronger. Both high and low body postures are common here, like in dominance aggression (Turcsan et al. 2011).

Fear-driven aggression - is the case in animals having been previously harmed by a strongly negative experience or those never having gone through socialization. It manifests itself very intensively, bites are extremely severe, and reflexes (such as urinating) are hardly 
controlled. It emerges when the dog sees no way of escape and is afraid of actual or imaginary danger. The body posture is low, with tucked tail and crouched legs.

Pain-induced aggression - the aroused dog does not let anyone touch the aching place. Fear of growing pain makes the dog defend. It may growl, hide that painful body part and eventually launch an attack (Cichon 2008).

Possession-related aggression - the dog may take objects belonging to the owners and protect them. An attempt to regain the property makes the dog growl, show teeth and possibly bite. A possible motivation is to verify its position in the hierarchy, tag playing, seeking clothes bearing the smell of pheromones, forced control of the human or compulsive finding of things, defense of a child and protection of food. In the dog's behavior, we can observe challenge and irritation (Pąsiek et al. 2015).

Maternal aggression - hormonal changes that occur during pregnancy and lactation may incite aggression. The aim is to protect the offspring against danger. An attack on a stranger may be violent and severe, while one launched on a friend is usually harmless. When a stranger approaches the puppies, the bitch takes a high posture and tries to scare the intruder away. If this does not work, she attacks. It is worth noting that the nest is often secluded and covered, with no way to escape. The attacking bitch may therefore also show fear (Max 2013).

Hunting aggression - most strongly manifested in primitive breeds and feral dogs. Hunting gives food, helps to spend excess energy and is an occasion to have fun. At home, where there is no shortage of food, cats, birds, rodents or children may represent the prey. The dog may force the victim to flee, than chases and finally catches it. This may repeat several times. It is referred to as hound aggression and is determined genetically; dogs of hunting breeds are more prone to hunting aggression. Early socialization of puppies with the vulnerable species allows us to avoid this problem; however, the instinct sometimes wins. During the chase, the increasing excitement and positive drive is the prize. It is contagious to other members of the pack. There are no typical facial expressions or body postures in this type of aggression. All we can see is the strong interest in the target, as manifested with a focus and gaze fixed on the prey (Iracka 2009).

Dislocated aggression - in this type of aggression, induced by various impulses, emotions are redirected on other objects. Strong arousal implies that it is hard to predict what will be the object attacked by the dog. This can be a neutral thing like a toy lying on the floor, or something limiting access to the irritating agent, e.g. the owner's hand holding the leash. The most vulnerable are easily irritable dogs, over-reactive, quickly losing the control of the body and of the strength of bites, as well as impulsive dogs that respond quickly, act immediately, and attack automatically, which makes them unpredictable and uncontrollable. The motivation here is the need to get rid of excess negative energy. The animal often behaves as if it did not realize that it has just attacked (Iracka 2009; Max 2013).

Idiopathic aggression - this type of behavior cannot by assigned to any specific type of aggression. It often results from physiological factors, therefore it is important to visit a vet, if we suspect this type of aggression. Diseases such as epilepsy, liver or thyroid disorders, neurological or infectious diseases may lead to an increased aggression level (Pąsiek et al. 2015). 


\section{AGGRESSIVE BEHAVIOR - APPRAISAL AND PREDICTION}

Functional appraisal is the process of gathering information on the observed behavioral incidents, which is aimed to work out a hypothesis and then to make a plan of intervention to change the behavior. It involves seeking the links between the environment and the behavior of the animal. The appraisal plan must allow for possible changes in the spread-over-time proceedings, since previously unrecognized response sources may need to be amplified or muted. The analysis involves four elements:

1. Motivating impulses - events that affect the motivation of the dog.

2. Differential stimuli - events most probably leading to problematic behaviors.

3. Problematic behavior - this stage involves defining and recognition of the behavior, as well as measuring frequency of its occurrence.

4. Consequences - these are changes in the environment resulting from aggressive behavior (Kuhne 2016).

O'Neill et al. (1997) propose another method to evaluate aggressive behavior, which involves six data categories:

1. Description of the incident, its duration and situations allowing predicting the eruption of unwanted behavior, or detection of situations of elevated likeliness that it might happen.

2. Detailed description of reactions and instrumental behaviors occurring together.

3. Characteristics of the consequences.

4. Description of emotional reactions that contribute to the problems.

5. Formulation of a hypothesis about the incident, preceding factors and amplifying problems.

6. Drawing conclusions from the observations, which allow gaining certainty as to the behavior and its function.

If the collected material fails to provide reliable information, functional analysis must be carried out. This is aimed at detailed examination of so-called preceding factors. Applying these factors with an additional stimulus, we can observe the resulting responses and differences between them. In a similar way, we carry out an analysis of outcomes, i.e. we introduce a variety of consequences of the given behavior and note the observed changes. This experiment reveals underlying hidden factors, i.e. those that change the probability and frequency of the behavior. The methods used in the experiment are reverse scheme and alternating scheme. There are two phases in the reverse scheme; first is to establish the frequency and amplitude of behavior. The next phase involves a variable - consequences and preceding factors. The experiment is replicated twice to avoid changes in behavior resulting from the lapse of time.

This may be illustrated with a dog on a leash biting strangers. If there are no strangers, there are no attacks. In the second phase a stranger appears and the attack is launched. We come back to the first stage, i.e. the stranger leaves the scene. As soon as they appear again, the dogs attacks anew. The response is quicker than in the first phase. The alternating scheme is characterized by rapid changes between two treatments. The variables are manipulated from the very beginning of the experiment, which is followed by observing how they affect the single incident. The modification consists in quenching the behavior, so it is the consequence and its opposite. Before the experiment, we must assess the risk for both the dog and its 
environment resulting from the experiment and prepare a strategy to minimize the threats. The experiment should be abandoned if the risk to any parties is too high, higher than the possible value of the analysis. All variables must be under control, since any irregularity may negatively influence the results. A detailed plan of the experiment with execution procedures should be prepared in advance (Goleman 2010; Pąsiek et al. 2015; Storgen and Lingaas 2015).

There is also a simpler method of assessing the level of risk. It consists of parameters and points assigned to each reaction:

1. Dog's body weight: the parameter is dog's body weight multiplied by four. This is because of the latent power of canine muscles. With certain impetus, the attack power is even stronger.

2. Vulnerable people: what matters here is the social status of the possible victim. The higher the parameter value, the higher the risk: $a$ - men, $b$ - women, apprehensive adults, slightly disabled persons, $\mathrm{c}$ - children over six years of age, elderly, moderately disabled people, $d$ - strongly disabled people, children over three and under six years of age, e - children under three years of age and heavily disabled adults.

3. Defensive or offensive aggression: the value of the parameter depends on the type of aggression; it is easier to avoid an attack by a defending dog, compared to an offensive attack: $a$ - defensive attack, $b$ - offensive attack.

4. Predictability of attacks: $a$ - predictable, warning phase occurs, $b$ - poorly predictable, the warning is not clear or lasts very shortly, $\mathrm{c}$ - unpredictable, there is no phase of warning.

5. Bite severity: the strength of the bite is what is important. $a$ - a nip without a trace, $b-a$ nip with a bruise, $\mathrm{c}-\mathrm{a}$ controlled bite with hematoma, $\mathrm{d}$ - controlled bite with a grip, e - skin and muscle damage by severe bites, $f$ - severe laceration by strong bites and grips, $\mathrm{g}$ - hunting bites tearing out a part of a muscle.

6. Multiplicity of bites: $a-$ single bite, $b-$ single bite with a grip, $c-$ multiple bites, $d$ - multiple bites (Dehasse 2006).

Accurate evaluation of the future character of a dog involves a range of factors, since a great number of variables may shape the mental development of the puppy. We are able, however, to determine the leading traits of the dog, which - if left untreated - may result in aggression. For this purpose, tests for young and adult dogs have been designed (Goleman 2010).

\section{RECAPITULATION}

Feral dogs use aggression to resolve conflicts, maintain the hierarchy in the pack, and to hunt for food. However, behavior considered normal in nature is unacceptable at home. Domestication and selection of dogs for desirable traits produced a dogs being a family friend and an indispensable companion in livestock works, game hunting or household guarding. Every dog owner should have appropriate knowledge on the breed, basic information on raising and training of dogs, as well as on how dogs communicate with other dogs or with people. Human body language differs from that of an animal. Signals that are positive for us, such as a wide smile, may represent a threat to a dog. Therefore, it is important to be conscious of our body language in the interactions with the dog. Aggression either may negatively affect the health or may be a symptom of a disorder. Diagnosing the aggression type and predicting 
its possible consequences is invaluable in preparation of a plan of actions aimed to change the behavior of the dog. Medical examination or pharmacological treatment may often be necessary. The observations allowed creating character tests for puppies, which are very useful for those who seek a good canine companion for the family.

Next to physical diseases and mental disorders, careless attitude and lack of imagination are the main factors underlying the possibility that the dog may grow dangerous.

\section{REFERENCES}

Cichon R. 2008. Agresywne zachowania psów. Wybrane elementy diagnostyki i terapii [Aggressive dog behavior. Selected elements of diagnosis and therapy]. Wet. Prakt. 2, 88-89. [in Polish]

Dehasse J. 2006. Agresja u psów. Postępowanie w przypadku zachowań agresywnych u psów. Łódź, Wydaw. Galaktyka. [in Polish]

Drews C. 1993. The concept and definition of dominance in animals behaviour. Behaviour 125, 283-313.

Duffy D.L., Hsu Y., Serpell J.A. 2008. Breed differences in canine aggression. App. Anim. Beh. Sci. 114, 441-460.

Fiszdon K., Boruta A. 2012. Analiza przypadków pokąsania przez psy. Część I. Jakie psy kąsają? [Analysis of dog biting incidents. Part I. Which dogs bite?]. Życie Wet. 87(12), 1022-1026. [in Polish]

Fleischer M. 2003. Komunikacja międzygatunkowa. Przypadek: człowiek-pies [Interspecific communication. Case: a man-dog]. Act. Univ. Wratislav., Język a Kultura 15, 223-242. [in Polish]

Goleman M. 2010. Wykorzystywanie testów dla szczeniąt przy ocenie przyszłego zachowania i charakteru psa [Use of puppy tests in the evaluation of future dog behavior and character]. Med. Weter. 66(6), 418-420. [in Polish]

Hsu Y., Sun L. 2010. Factors associated with aggressive responses in pet dogs. App. Anim. Beh. Sci. 123, 108-123.

Haverbeke A., De Smet A., Depiereux E., Giffroy J.M., Diederich C. 2009. Assessing undesired aggression in military working dogs. App. Anim. Beh. Sci. 117, 55-62.

Horn L. Range F., Huber L. 2013. Dogs' attention towards humans depends. On their relationship, not only on social familiarity. Anim. Cogn. 16, s. 435-443.

Iracka J. 2009. Agresja łowcza [Aggression to hunt]. Mój Pies 6, 68. [in Polish]

Kokocińska A, Kaleta T. 2015. Behawioryzm i behawior - myśl filozoficzna i badania przyrodnicze [Behaviorism and behvior: philosophy and behavioral methods]. Probl. Nauk Biol. 64(307)2, 221-227. [in Polish]

Kuhne F. 2016. Behavioural responses of dogs to dog-human social conflict situations. App. Anim. Sci. 182, 38-43.

Max A. 2013. Instynkt macierzyński i jego zaburzenia u suk i kotek [Maternal instinct and its disturbances in bitches and queens]. Mag. Weter. 22, 76-79.

McFarland D. 1999. Animal behawior. Horlow, Pearson Education Limited.

O’Neil R.E., Horner R.H., Albin R.W., Sprague J.R., Storey K., Newton J.S. 1997. Fundactional assessment and program development for problem behavior. A practical guide. Brooks/Cole Scarborough, Cengage Learning Inc.

Pąsiek M., Majecka K., Pietraszewski D. 2015. Pies baskervillów - czyli o naturze zachowań agresywnych u psa domowego canis lupus familiari [The hound of the baskervilles - the true nature of aggressive bahaviour in the domestic dog Canis lupus familiaris]. Kosmos 2, 239-246. [in Polish]

Storengen L.M., Lingaas F. 2015. Noise sensitivity in 17 dog breeds: Prevalence, breed risk and correlation with fear in other situations. App. Anim. Beh. Sci. 171, 152-160.

Turcsan B., Kubinyi E., Miklosi A. 2011. Trainability and boldness traits differ between dog breed clusters based on conventional breed categories and genetic relatedness. App. Anim. Beh. Sci. 132, $61-70$. 
Abstract. Recognizing the signs of aggression in dogs is closely related to the capability of distinguishing the signals which the dog sends to the other individual. In the second part of this article, we will take a closer look at the character of particular signals and actions elicited by the signals. We also focus on how to evaluate and predict aggressive actions in dogs, so that the owner can be better prepared to interactions with the dog and to properly understand its intentions. 